\title{
THE DESCRIPTION OF TEACHERS' STRESSOR AND MANIFESTATION OF SPECIAL NEEDS TEACHERS IN INCLUSIVE AND SPECIAL SCHOOLS IN JAKARTA
}

\author{
Yapina Widyawati and Felicia \\ Psychology Faculty of Atma Jaya Catholic University Jakarta \\ yapina.widyawati@atmajaya.ac.id \\ https://doi.org/10.24071/ijiet.v1i1.327
}

\begin{abstract}
Teachers for special needs children are needed in inclusive and also in special schools (SLB). In inclusive schools, teachers who teach special needs children usually the class teacher or subject teacher. They usually have general pedagogic educational background. They were not specialized in teaching exceptional children. While on SLB, teacher had educational backgrounds from special education pedagogic. Both of them were dealing with different characteristics and their respective obligations demands. This situation could become a stressor that could affect learning. This research is a descriptive study. Characteristics of the sample in this study are that teachers who are between 20 and 65 years old, men and women, who teach at the elementary nation Inclusion and SLB. Participants obtained by the accidental sampling method were 67 people. Study showed that their stressor was from specific events relating to work. Source of their mild stress was setting time balance between personal time and work. A manifestation of stress occurs in the form of fatigue arising with regard to the perceived pressure. To reduce or minimize the stress that arises, necessary training and seminars to enrich their knowledge were needed, their also need goodcommunication between the teacher and the school and build tolerance among co- workers.
\end{abstract}

Keywords: stress, manifestasion, special needs teacher, inclusion, special school

\section{Introduction}

Being a teacher for children with special needs is one of the professions which cause high stress. Teacher for special education usually enjoys challenges in handling children with special needs (Anak Berkebutuhan Khusus). The teacher also has a chance to build close relationship with the children. This profession is usually appreciated, yet it also consumes energy physically or even emotionally ("TeacherSpecial Education", 2009). A study conducted by Ken Mrozek shows that teacher is one of the professions which can cause stress. It is shown from the turnover percentage which is higher, compared to other social professions, such astranslator and social worker. Specifically, according to turnover percentage, children with special needs teacher has high percentage to leave his/her jobs compared to other teachers, such as Homeroom teachers, Math teachers, Science 
teachers, Elementary School teachers, English teachers and Social teachers (in Mrozek, n.d.).

In Indonesia, a teacher of children with special needs' is able to teach in special educational institutions, namely a special school (SLB) and inclusiveschool. SLB is a school designed for children with special needs from one type ofdisorders ("Mengenal Pendidikan", 2006). On the other hand, inclusive school is aschool employing educational system in which children with special needs can learn together with normal children using many facilities in that school (Sanyoto, 2006). Inclusive Education is developed based on the basic principle that education is for all people. Besides, the curriculum is compiled based on the children's needs including special needs'. Therefore, it needs flexibility, creativity, and sensitivity (Skjørten, 2001).

In every special education service, teacher's role is a one of the factor which determines whether the learning process is success or not. Other factors are curriculum and learning strategy in class. Teacher is a human unit which is close to children in the daily education activities in school. Sometimes, children see teacher as identity figure, so that teacher can guide and lead children in the learningteaching activity, and then it finally determines whether the children can achieve the goals or not (Direktorat Pembinaan Sekolah Luar Biasa, 2006).

Sudrajat (2008) states that a teacher should manage many things to support the learning process. The supporting things are formulating precise learning goals, selecting appropriate strategy or learning methods, giving guidance or counseling, facilitating and motivating students, assessing learning outcomes fairly, establishing a good interaction with the students, and creating conducive learning atmosphere. Creating conducive learning atmosphere depends on comfortable and fun learning conditions.

A teacher in Special school is a teacher having educational background in Special Education Major. Those teachers have already had some competences and abilities to handle children with special needs. On the other hand, teachers in inclusive school are homeroom teacher and subject teachers assisted by special education teacher. Based on the observation on 1 regular school which has one special student and 1 inclusive school, the teacher is not required to have special educational background.

Allen and Schwartz (2001) state the same thing that the teacher in either inclusive school or special school should be able to handle children with various abilities. According to Hargreaves, teacher's professionalism is exposed from the knowledge and ability in handling various students, and ability to support and develop each other. Moreover, teacher should be able to accept any criticism. This professionalism can generate positive emotion towards teacher (Troman \& Woods, 2001). According to Woods and Jeffrey in the same source, teacher having positive emotion can inspire and motivate their students and also haveclose relationship. When teacher is not professional, the teacher will be led by negative emotion.

Kyriacou states that a negative emotion involving pressure, restlessness, anger, depression, and frustration because of certain experience and working condition is called stress (Giddens, 2005). In a study of stress among teachers, 
there are 4 factors generating stress, namely student's behavior, limited facilities and time, less appreciation, and bad relation with other teachers (Kyriacou \& Pei, 2004). Those things affect teacher's performance in the learning process. In school, manifestation which is not routed properly can induce careless or even aggressive attitudes towards colleague or students (Tsai, Fun \& Chow, 2006).

Therefore, researcher is interested in analyzing the description of stress source and manifestation experienced by teachers of inclusive school and special schools. Thus, it can help teachers to identify the source and manifestation stress. The research question is: How are stress source and manifestation towards special needs' teachers in inclusive schools and special schools depicted?

This study is descriptive research aiming to discern the description of stress source and manifestation towards special needs' teachers in inclusive school and special school. This study gives contribution towards the development and improvement of inclusive and special schools in Indonesia. This study provides information for teachers in inclusive and special schools regarding the depiction of stress that teachers experience. This study also provides knowledge regarding the source of the teacher's stress so that they can design appropriate strategy for coping with the stress. Besides, this study can give suggestion towards engaged parties, such as headmaster and parents.

\section{Method}

This study is a descriptive research since the researcher intended to see the depiction of stress source and manifestation towards special needs' teachers in inclusive and special schools. This study employed quantitative and nonexperimental approach since the researcher cannot manipulate the variable.

The researcher wanted to discern the depiction of stress source and manifestation towards special needs' teachers in inclusive and special schools. Thus, stress becomes the variable in this study. Operational definition of stress towards special needs' teachers in inclusive and extraordinary teachers is the total score of items in every domain which represent source and manifestation from uncomfortable experience. And then, it generates a negative emotion such as anger, frustration, restlessness, depression, and tense as a result of interaction because of teaching special needs' in inclusive and special schools.

The subjects in this study were special needs' teachers in inclusive and special schools having some criteria as follows: a. Subjects were homeroomteacher or subject teachers or special education teachers in inclusive schools and SLB and b. Subjects had at least one or more students categorized as children with special needs in one class. The numbers of subjects in this study were 31 subjects in SLB and 36 subjects in inclusive school.

Inclusive schools as the subject were public schools since these publicschools had the same characteristics. Since the operational schools were paid by government, all supporting facilities will be similar. On the other hand, the special schools were private schools.

The data were collected through accidental sampling method, which is included as non-random sampling as the data collection technique. In this technique, the subjects are selected based on the location of the population, yet 
they still meet the characteristics that researcher wants (Kumar, 1999). In this study, researcher visited the inclusive and special schools to ask teacher to fulfill the questionnaire.

The instrument used is Teacher Stress Inventory (TSI) to measure stress towards special needs' teachers in inclusive and special schools. TSI is an instrument to identify the stress source and its manifestation towards the stress. The domains in the instrument are Professional Investment, Time Management, Workrelated Stressors, Discipline and Motivation, Professional Stress, Behavioral Manifestations as extended stress manifestation (Ritz, 2009 \& Olivier, 2003). Domains of Manifestation towards stress are Emotional Manifestations, Gastronomical Manifestations, Cardiovascular Manifestations, and Fatigue Manifestations (Ritz, 2009 \& Olivier, 2003). In TSI, those ten factors are represented in 49 items using 5 scales, namely do not very agree, do not agree, neutral, agree, and very agree. In this study, Reliability examination employed Cronbach's Alpha, 0.903.

\section{Results and Discussion}

\section{Description of Demography Data}

Seventy-one questionnaires were distributed to 8 schools (Inclusive school and Special School). Out of 71 questionnaires, 4 questionnaires were not used as the data. Overall, 67 questionnaires were used as the data. The following table shows demography description of subjects.

Table 1. The Description of Subject Demography Data

\begin{tabular}{|c|c|c|c|c|c|}
\hline \multirow{2}{*}{ Age } & \multicolumn{2}{|l|}{ Inclusive } & \multicolumn{2}{|c|}{ Special school } & \multirow[t]{2}{*}{ Total } \\
\hline & f & $\%$ & $\mathbf{f}$ & $\%$ & \\
\hline $21-25$ & 2 & 10,5 & 1 & 3,2 & 3 \\
\hline $26-30$ & 1 & 2,8 & 2 & 6,5 & 3 \\
\hline $31-35$ & 2 & 10,5 & 4 & 12,9 & 6 \\
\hline $36-40$ & 5 & 13,8 & 2 & 6,5 & 7 \\
\hline $41-45$ & 6 & 16,6 & 9 & 29 & 15 \\
\hline $46-50$ & 11 & 30,5 & 9 & 29 & 20 \\
\hline $51-55$ & 7 & 19,4 & 3 & 9,7 & 10 \\
\hline $56-60$ & 2 & 10,5 & 0 & 0 & 2 \\
\hline $61-65$ & 0 & 0 & 1 & 3,2 & 1 \\
\hline \multirow{2}{*}{ Sex } & \multicolumn{2}{|l|}{ Inclusive } & \multicolumn{2}{|c|}{ Special school } & \multirow[t]{2}{*}{ Total } \\
\hline & f & $\%$ & $\mathbf{f}$ & $\%$ & \\
\hline Female & 30 & 83,3 & 22 & 71 & 52 \\
\hline Male & 6 & 16,7 & 9 & 29 & 15 \\
\hline \multirow{2}{*}{$\begin{array}{l}\text { Work experience } \\
\text { Work experience } \\
\text { (in years) }\end{array}$} & \multicolumn{2}{|l|}{ Inclusive } & \multicolumn{2}{|c|}{ Special school } & \multirow[t]{2}{*}{ Total } \\
\hline & $\mathbf{f}$ & $\%$ & $\vec{f}$ & $\%$ & \\
\hline $0-5$ & 20 & 55,6 & 3 & 9,7 & 23 \\
\hline $6-11$ & 16 & 44,4 & 3 & 9,7 & 19 \\
\hline $12-17$ & 0 & 0 & 9 & 29 & 9 \\
\hline $18-23$ & 0 & 0 & 7 & 22,6 & 7 \\
\hline $24-29$ & 0 & 0 & 7 & 22,6 & 7 \\
\hline
\end{tabular}


IJIET Vol. 1, No. 1, January 2017

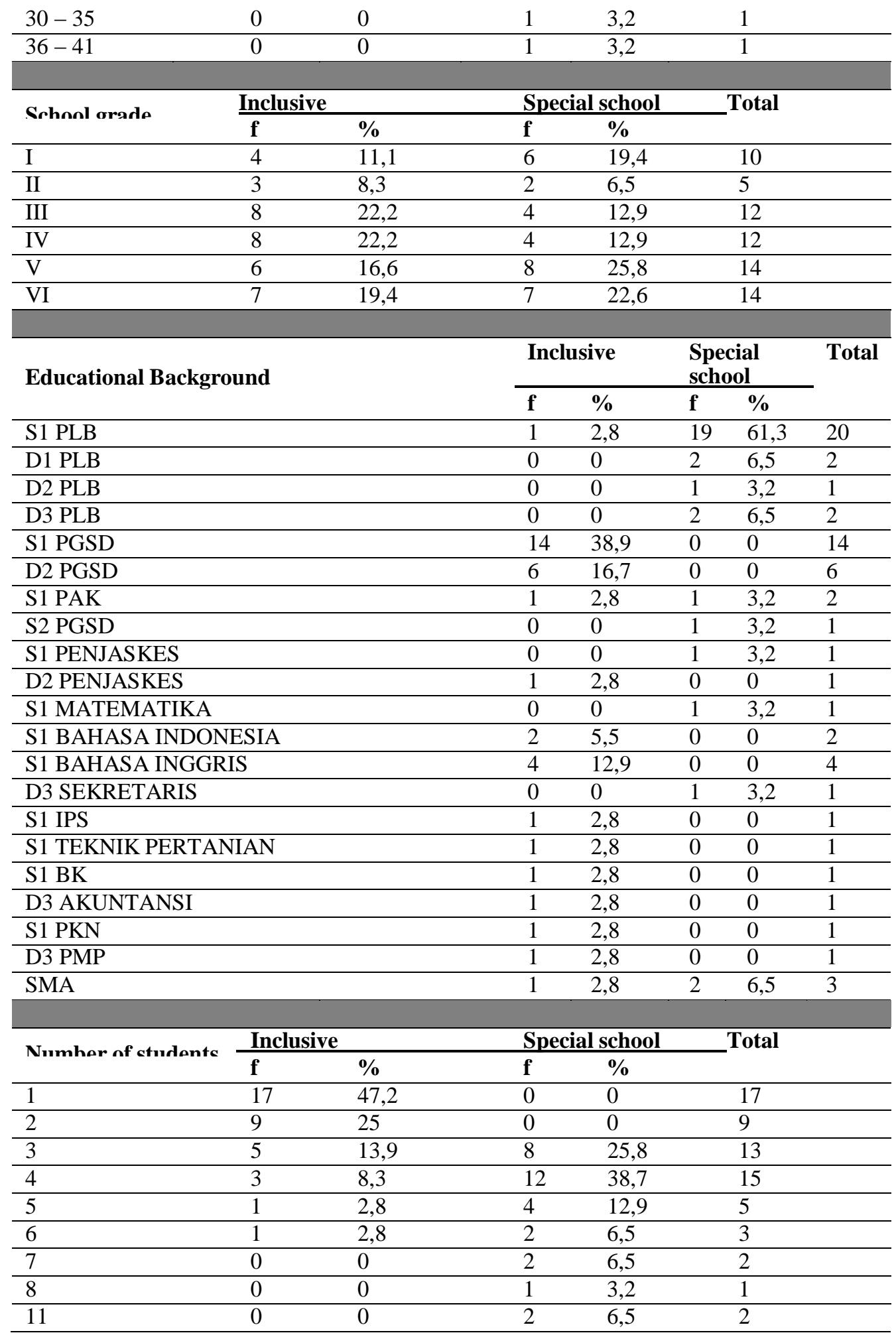


IJIET Vol. 1, No. 1, January 2017

Table 2. The Description of the Numbers of special needs' Variation and Characteristic in 1 Class

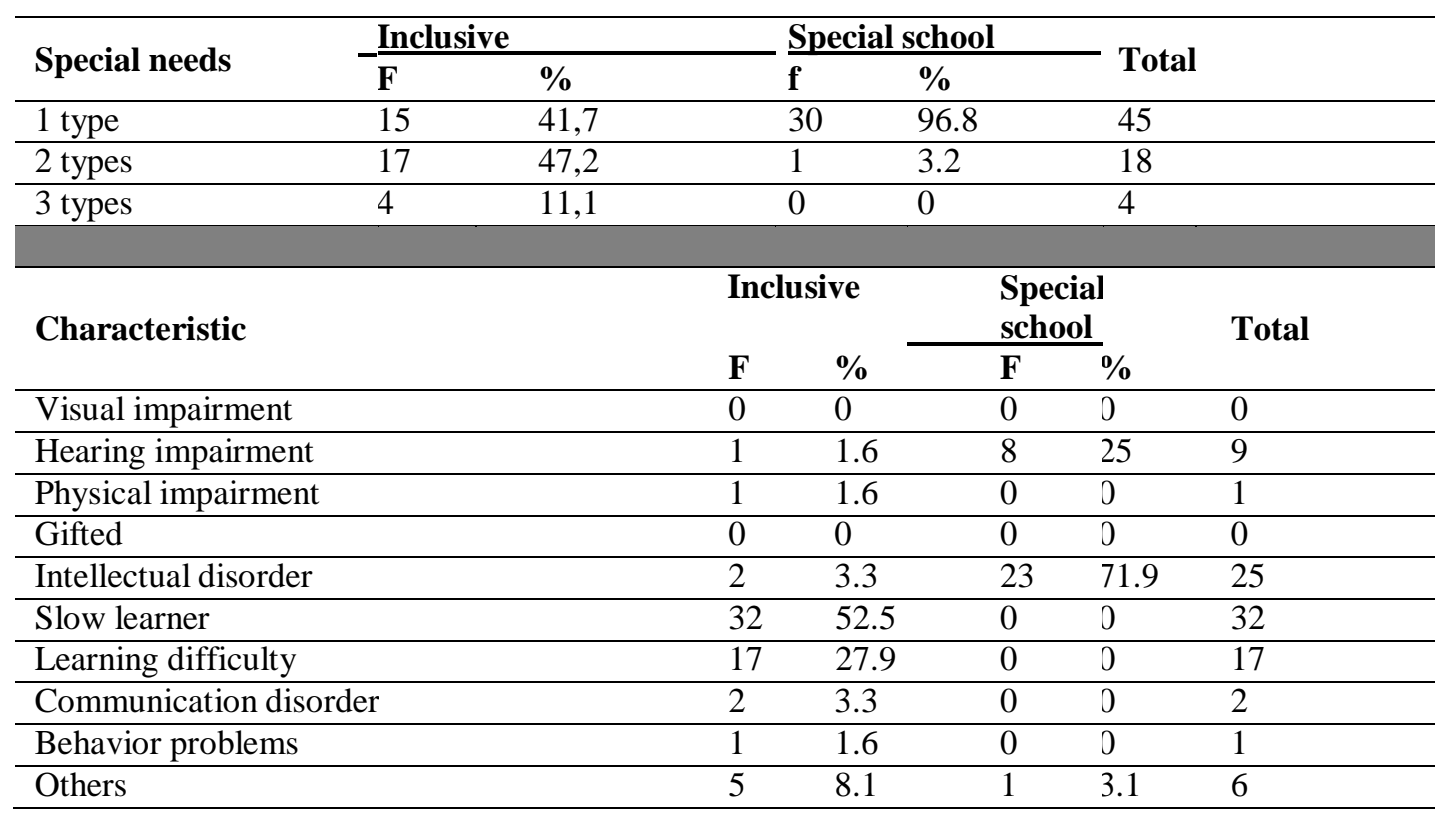

This section shows the calculation based on the source of stress from 36 questionnaires in inclusive school and 31 questionnaires in Special School (SLB).

\section{The Description of Comparative Stress Source}

Table 3. The Description of Comparative Stressor in Inclusive School

\begin{tabular}{|c|c|c|c|c|c|c|}
\hline $\begin{array}{l}\text { Stress } \\
\text { level }\end{array}$ & $\begin{array}{l}\text { Professional } \\
\text { Investment }\end{array}$ & $\begin{array}{l}\text { Time } \\
\text { Management }\end{array}$ & $\begin{array}{l}\text { Work } \\
\text { Related } \\
\text { Stressor }\end{array}$ & $\begin{array}{l}\text { Discipline } \\
\text { Motivation }\end{array}$ & $\&$ & $\begin{array}{l}\text { Professional } \\
\text { Stress }\end{array}$ \\
\hline Mild & $25(69.4 \%)$ & $29(80.5 \%)$ & $4(11.1 \%)$ & $26(72.2 \%)$ & & $13(36.1 \%)$ \\
\hline Medium & $11(30.6 \%)$ & $6(16.7 \%)$ & $30(83.3 \%)$ & $10(27.7 \%)$ & & $23(63.9 \%)$ \\
\hline High & 0 & $1(2.8 \%)$ & $2(5.6 \%)$ & 0 & & 0 \\
\hline
\end{tabular}

It shows that Time Management domain has the highest percentage as a stressor of special needs' teachers in inclusive school in the low level. In the medium and high level, Work Related Stressor has the highest percentage.

Table 4. Description of Comparative Stressor Source in Special school

\begin{tabular}{|c|c|c|c|c|c|c|}
\hline $\begin{array}{l}\text { Stress } \\
\text { level }\end{array}$ & $\begin{array}{l}\text { Professional } \\
\text { Investment }\end{array}$ & $\begin{array}{l}\text { Time } \\
\text { Management }\end{array}$ & $\begin{array}{l}\text { Work Related } \\
\text { Stressor }\end{array}$ & $\begin{array}{l}\text { Discipline } \\
\text { Motivation }\end{array}$ & $\&$ & $\begin{array}{l}\text { Professional } \\
\text { Stress }\end{array}$ \\
\hline Mild & $23(74.2 \%)$ & $27(87.1 \%)$ & $11(35.5 \%)$ & $24(77,4 \%)$ & & $17(54.8 \%)$ \\
\hline Medium & $8(25,8 \%)$ & $4(12.9 \%)$ & $18(58 \%)$ & $6(19,3 \%)$ & & $14(45.2 \%)$ \\
\hline High & 0 & 0 & $2(6.5 \%)$ & $1(3,2 \%)$ & & 0 \\
\hline
\end{tabular}


It shows that the stressor of mild stress in special school is Time Management. Meanwhile, Work Related Stressor becomes the source of medium and highstress.

Table 5. The description of Comparative Stressor in Overall

\begin{tabular}{lllllll}
\hline $\begin{array}{l}\text { Stress } \\
\text { level }\end{array}$ & $\begin{array}{l}\text { Professional } \\
\text { Investment }\end{array}$ & $\begin{array}{l}\text { Time } \\
\text { Management }\end{array}$ & $\begin{array}{l}\text { Work Related } \\
\text { Stressor }\end{array}$ & $\begin{array}{l}\text { Discipline } \\
\text { Motivation }\end{array}$ & \& & $\begin{array}{l}\text { Professional } \\
\text { Stress }\end{array}$ \\
\hline Mild & $48(71.6 \%)$ & $56(83.6 \%)$ & $15(22.4 \%)$ & $50(74.6 \%)$ & $30(44.8 \%)$ \\
\hline Medium & $19(28.4 \%)$ & $10(14.9 \%)$ & $48(71.6 \%)$ & $16(23.8 \%)$ & $37(55.2 \%)$ \\
\hline High & 0 & $1(1.5 \%)$ & $4(6 \%)$ & $1(1.5 \%)$ & 0 \\
\hline
\end{tabular}

The table shows that Time Management becomes the stressor of mild stress. Meanwhile, the stressor in the medium and high levels is Work Related Stressor.

\section{The Description of Comparative Stress Manifestation}

This domain is measured through close-ended questions using Never, Seldom, Often, and Always scales. This section provides the calculation of 36 questionnaires in inclusive school and 31 questionnaires in SLB based on domain in the form of stress manifestation.

Table 6. The Stress Manifestation Forms in Inclusive School and SLB

\begin{tabular}{llll}
\hline \multirow{2}{*}{ Domain } & \multicolumn{2}{l}{ Average score } & \multirow{2}{*}{ Significance } \\
\cline { 2 - 3 } & Inclusive & Special school & \\
\hline Behavioral Manifestation & 1.042 & 1.113 & 0.013 \\
\hline Emotional Manifestation & 1.507 & 1.734 & 0.774 \\
\hline Gastronomical Manifestation & 1.375 & 1.612 & 0.006 \\
\hline Cardiovascular Manifestation & 1.625 & 1.532 & 0.586 \\
\hline Fatique Manifestation & 1.763 & 1.935 & 0.471 \\
\hline
\end{tabular}

It shows that fatigue manifestation has the highest average score. It means that physically response such as fatigue is the most frequent manifestation experienced by special needs' teachers in inclusive school. Meanwhile, behavioral manifestation has the lowest average score. It means that manifestation which is seldom emerged is behaviors such as consuming sedative and alcohol. The significant differences are in behavioral manifestation and gastronomical manifestation domains.

\section{Discussion}

The result of this study shows that there is similarity towards stressor and manifestation experienced by special needs' teachers in inclusive schools and special school (SLB). The most interesting thing is special needs' teachers experience medium and high stress because of specific jobs as teachers, such as teaching preparation, workload, classroom size, administrative task and responsibility towards school. On the other hand, time management between individual and educator activities becomes the cause of light stress. It is related to 
additional time given to work on additional task as teacher. Usually, it is related to the excessive workload. A teacher who cannot have personal time usually experiences stress higher than the others (Boyer-Colon, 2009). The result of this study is different from what Boyer-Colon (2009) has stated. The results show that special needs' teachers can manage their personal time well although they face pressure and demand beyond their abilities.

In inclusive school and special school (SLB), a good time management is related to the teaching length, or the experience length as special needs' teacher. Someone can be easier to manage his/her time if they have already accustomed to that. According to Dr. Gersten, (in Giddens, 2005) teacher has stress when the teacher has little experience to handle students with various abilities. The majority of the teachers as subject in special school had 12-29 years of experience. Meanwhile, the teacher in inclusive school has 0-11 years of experience. The time experience in inclusive school is still short since inclusive school is still new in Indonesia, starting around 2004-2005 (Mengenal Pendidikan Inklusi, 2006).

The unprepared matter upon specific demands in work makes teacher feel stress. In inclusive school, the unprepared thing is an effect of the changing curriculum from homogeny class into heterogenic class. This changing is needed since heterogenic is one of the characteristics in inclusive school as suggested by Sapon-Shevin. In this case, teacher needs adaptation and when teacher cannot adapt, they will experience stress (Mengenal Pendidikan Inklusi, 2006). Adaptation will be difficult when there is no sufficient knowledge related to the job or work. Thus, training upon special needs' is needed. During this time, teachers still had difficulties to explain the concept of the subjects since the assigned teacher, notably non special education teacher, experiences some limitation in articulating a concept from a subject to the students with special needs ("Pendidikan Inklusi belum memadai", 2011). The subjects in inclusive school were homeroom teachers. The special education teacher (Guru Pendamping Khusus) as subject teachers was only one since GPK was not always provided in the school.

Meanwhile, in special school (SLB), the lack of preparation in handling specific demands is related to the numbers of special needs' in 1 classroom. The numbers of special needs' in one classroom were between 3-11 students. The more numbers of special needs' in the class, the more responsibilities for teaching preparation, workload, class size, and administrative task are needed. In SLB, there was no teacher assistant in 1 class. As well as inclusive school, teachers in SLB still need training. Based on the data, the majority of special needs' teachers, in both inclusive school and SLB, have not had any seminar or training related to special needs'.

Based on the calculation, the majority of special needs' teachers, in both inclusive school and SLB, experienced fatigue manifestation. It means that the most frequent manifestation which emerges towards special needs' teachers is the form of physical response, fatigue. Meanwhile, the minority experienced behavioral manifestation such as consuming sedative or even alcohol. Whatever the form of manifestation is, the most important thing is how to solve it. The form of manifestation which is left for a long time can cause serious pathology 
symptoms. Moreover, it can cause self-destructive behavior, such as suicide. In the school, the manifestation which is not routed can cause careless or even aggressive behaviors towards colleagues or students (Tsai, Fung and Chow, 2006).

In this study, the researcher realizes that there are still many imperfections, such as the unfair distribution of subject sampling, especially in the inclusive schools. It is because inclusive school is not located in every region. Other imperfection related questionnaire distribution is researcher had to leave the questionnaires at school as suggested by the school. It makes the researcher cannot directly give clear explanation towards questionnaires. Should the imperfections above resolve, it can give better result for this study.

\section{Conclusion}

There are three conclusions that can be drawn from this study. First, there is a similar light stress experienced by special needs' teachers in Inclusive School and SLB regarding how teachers balance their time and activity as educators (Ritz, 2009). It also includes time to calm them, time to prepare, and other needed times (Oliver, 2003). Second, there is a similar trait of medium and heavy stress experienced by special needs' teachers in inclusive school and SLB regarding specific events related to their jobs (Ritz, 2009). For instance, teaching preparation, workload, classroom size, administrative tasks and responsibility towards school (Oliver, 2003). Third, the most frequent manifestation emerging ininclusive school and special school is fatigue regarding stress (Ritz, 2009). One of the forms is sleep disorder (Oliver, 2003).

As for the recommendations, it is better to increase the the number of special needs teachers, more heterogonous in special needs' characteristics, more even distribution in every regional in Jakarta to achieve more various descriptions.

The direct instruction in filling the questionnaires is needed to anticipate misinterpretation within subjects. After collecting the data through questionnaire, interview is needed to investigate in depth the stress source and manifestation conducted by the teachers. In addition, it aims to add stress coping to depict better description. Developing the instrument, especially the behavioral manifestation domain should be more relevant and in line with the condition in Indonesia.

Regarding inclusive schools, it is good if government or school can provide training or seminar to enrich teacher's knowledge, especially, related to inclusive education such as curriculum or teaching method development. From teachers, they have to have willpower to learn about inclusive since it is still new in Indonesia. They also have to be open-minded to accept new information related to teaching special needs' since it may be different from their experiences. For special schools, the government or school is expected to provide training or seminars to enrich teacher's knowledge with much new information related to children with special needs, such as device development which can support every student needs. From teachers, they have to communicate every uncomfortable things to school, for example, providing facilities for teaching preparation. For both schools, all teachers are expected to establish tolerance among colleagues so 
that they will establish empathy. Finally, colleagues can help each other to solve stress.

\section{References}

Alay, S \& Kocak, S. (1999). A Study of Stress, Symptoms and Strategies of Physical Educators in Elementary Schools. Retrieved from efdergi.hacettepe.edu.tr/199916SEMAALAY.pdf

Allen, K. E \& Schwartz, I. S. (2001). The exceptional child: Inclusion in early childhood education $\left(4^{\text {th }} \mathrm{ed}\right)$. New York: Thomson Learning Inc.

Anastasi, A \& Susana, U. (1997). Psychological testing. Upper Saddle River, NJ: Precentice Hall, Inc.

Barokah, S. (2008). Moralitas Peserta Didik Dalam Pendidikan Inklusif. [Versi elektronik]. Skripsi Program Magister. Institut Agama Islam Walisongo

Boyle, G. J., Bork, M. G., Falzon, J. M \& Baglioni, A. J. (1995). A structural model of the dimensions of teacher stress. British Journal of Educational Psychology, 65, 49-67.

Cruickshank, W. M \& Johnson, G. O. (1962). Education of exceptional children and youth. : Prentice-Hall.

Cosgrove, J. (2001). Breakdown : The Facts About Teacher Stress. London : Taylor \& Francis e-Library.

Ditjen PLB. (2006). Mengenal pendidikan inklusif. Diakses pada tanggal 20 September 2008 dari ditplb.or.id

Direktorat Pembinaan Sekolah Luar Biasa. (2006). Pengadaan dan Pembinaan Tenaga Kependidikan dalam Pendidikan Inklusif. Diakses pada 20 September 2008 dari ditplb.or.id/2006/index.php?menu=profile \&pro=57

Direktorat Pembinaan Sekolah Luar Biasa. (2006). Pengembangan Kurikulum Dalam Pendidikan Inklusi. Diakses pada 12 November 2008 dari ditplb.or.id/profile.php?id=55

Faiz, P. M. (2006). Penelantaran Pendidikan: Perspektif Hukum terhadap Hak Memperoleh Pendidikan. Diakses pada 25 November 2008 dari panmohamadfaiz.com/ 2006/12/03/penelitian-hukum-perspektif-hukumterhadap-penelantaran-pendidikan/

Giddens, E. N. (2005, Juni).Stress Factor In A Comparative Study Between Special Educators and Reguler Educators. [Versi elektronik]. Disertasi Doktoral. Capella University, Minneapolis.

Gravetter, F. J \& Wallnau, L. B. (2004). Statisic for the Behavioral Science (6 ${ }^{\text {th }}$ ed). New Zealand : Thomson Learning,

Hanif, R .(2004). Teacher Stress, Job Performance, and self efficacy of Women School Teachers. [Versi Elektronik]. National Institute of Psychology/ Quaid-i-Azam University, Islamabad

Herawaty, D. (2005). Perbedaan Persepsi Terhadap Sumber Stres Kerja Antara Guru Sekolah Dasar dan Guru Sekolah Luar Biasa Di Jakarta Barat. Skripsi sarjana, tidak diterbitkan. Universitas Katolik Indonesia Atma Jaya, Jakarta.

Kumar, R. (1999). Research methodology : a step-by step guide for beginners. London : Sage Publication.

Kyriacou, C. (2000). Stress-busting for teachers. Nelson Thornes. 
Kyriacou, C \& Pei, Y. C. (2004). Teacher stress in taiwanese primary schools. [Versi elektronik]. Journal of Educational Enquiry, 5(2), 86-104

Masduqi, B. F. (2008, Juli). Dilema Pendidikan Inklusi di Negara Kita. Diakses pada 25 November 2008 dari jawapos.co.id/metropolis/index.php?act=detail\&nid=9292

Mengenal Pendidikan Inklusi. (2006). Diakses pada 20 September 2008 dari ditplb.or.id/2006/index. php?menu=profile \&pro $=42$

Miller, G., Brown-Anderson, F., Fleming, W., Peele, T., \& Chen, M. (1999). Teacher Stress: A Case Study.

Morgan, C. T. (1986). Introduction To Psychology (7th ed). McGraw-Hill Book Company : Singapore

Mrozek, K. (t.th). Teacher Stress. [Versi elektronik]. Diakses pada 6 Juli 2009 dari cedu.niu.edu/ s humow/itt/Teacher\%20Stress.pdf

Multahada, E. (t.th). Pengantar Psikologi Industri dan Organisasi. [Versi elektronik]. Pusat Pengembangan Bahan Ajar: UMB.

Oliver, M. A. J. (2003). The extent and causes of stress in teacher in the George region. [Versi elektronik]. South Africa Journal of Education. Vol 23(3) 186192

Pamangsah, Anang. (4 Oktober 2008). Penangulangan stres kerja: Stres Akibat Kerja Yang Dihadapi Oleh Guru Sekolah Luar Biasa. Diakses pasa tanggal 12 Maret 2009 dari pamangsah.blogspot.com/2008/10/penangulanganstress-kerja.html

Pengadaan dan Pembinaan Tenaga Kependidikan dalam Pendidikan Inklusif. (2006). Diakses pada 20 September 2008 dari ditplb.or.id/2006/index.php?menu=profile \&pro $=57$

Pengantar Pendidikan Luar Biasa. (2008). Diakses pada 22 September 2008 dari pustaka.ut.ac.id/puslata/ online.php?menu=bmpshort_detail $2 \& I D=282$

Rini, J. F. (1 Maret 2002). Stress Kerja. [Versi elektronik]. Bali Usada Meditation.

Ritz, R. A. (Agustus, 2009). The Effects of a Time Management Seminar on Stress and Job Satisfaction of Beginning Agricultural Science Teachers. [Versi elektronik]. Disertasi Doktoral. Texas Tech Unoversity

Sanyoto, M. H. (2006). Perlunya Penanganan Pendidikan Anak Berkebutuhan Khusus. Diakses pada 25 September 2008 dari ditplb.or.id/2006/index.php?menu= profile $\&$ pro $=181$

Sekolah atau Tidak Sekolah-Sebuah Pilihan. (2008, 9 Mei). Pesan ini disampaikan pada puterakembara.org/archives/00000297.shtml

Skjørten, M. D. (2001). Menuju Inklusi dan Pengayaan. [Versi elektronik]. Diakses pada 8 November 2008 dari idp-europe.org/indonesia/bukuinklusi/Menuju_Inklusi_dan_Pengayaan.php

Sudrajat, A. (2008). Psikologi Pendidikan dan Guru. Diakses pada 12 November 2008 dari akhmadsudrajat. $\quad$ wordpress.com/2008/02/02/psikologi-pendidikan-danguru/

Sukadari. (t.th). Peran Pendidikan Inklusi Bagi Anak Berkelainan. Diakses pada 27 September 2008 dari madinask.com/index.php?option=comcontent $\&$ task $=$ view $\&$ id $=812 \&$ Itemid $=10$ 
Surbakti, E. P (2008). Stres dan koping Lansia Pada Masa Pensiun di Kelurahan Pardomuan Kecamatan Siantar Timur Kotamadya Pematangsiantar. [Versi elektronik]. Skripsi Sarjana. USU Rpository.

Teacher-Special Education (2009). Occupational Outlook Handbook, 2010-11 Edition. Diakses tanggal 5 Januari 2010 dari bls.gov/oco/ocos070.htm

The UNESCO Salamanca Statement in a nutshell. (2008). Diakses pada 10 November 2008 dari csie.org. uk/inclusion/unesco-salamanca.shtml

Troman, G \& Woods, P. (2001). Primary Teacher Stress. London : Routledge \& Kegan.

Udin, T \& Tejaningsih, E. (1988). Dasar-dasar PLB: Pendidikan Luar Biasa SPG/SGO/KPG. Bandung: Epsilon Group.

Utama, D . K.(2005). Sekolah Alam: Bantuan Untuk Anak Dengan Kebutuhan Khusus Dengan Mendekati Alam. Diakses pada 8 Juli 2009 dari 74.125.153.132/search

?q=cache:2UznqdAN9awJ:sekolahalambandung.com/blogs/2005/09/29/trai ning-psikologi-di-

$\mathrm{sab} /+$ faktor+keberhasilan+belajar+ABK\&cd=17\&hl=id\&ct=clnk\&gl=id

Wahyuni, T. (2005). Pendidikan: Guru SLB Kian Langka. Diakses pada 25 November 2008 dari suarakarya-online.com/news.html?id=122530

William, K \& Poel, E. W. (2006, September). Stress Management for Special Educators: The Self-Administered Tool for Awareness and Relaxation (STAR). [Versi Elektronik]. Teaching Exceptional Children Plus Vol. 3, Issue 1.

Tsai, E., Fung, L. \& Chow, L. (2006). Source and Manifestations of Stress in Female Kindegarten Teachers. [Versi Elektronik]. International Education Journal, 7 (3), 364-370

Boyor-Colon, C.C. (2009). Teacher stress among catholic high school teachers: Its nature and sigificance. Disertasi doktoral. University of America, Washington DC

Larno. (Maret, 2012). Kemendikbud-HKI Luncurkan Panduan Mengajar Sekolah Inklusi. Diakses pada 23 Maret 2012 dari http://kepri.antaranews.com/berita/19898/kemendikbud-hki-luncurkanpanduan-mengajar-sekolah-inklusi

(November, 2011). Layanan Pendidikan: Pendidikan inklusi masih diabaikan. Diakses pada tanggl 23 Maret 2012 dari http://edukasi.kompas.com/read/2011/11/11/0433535/Pendidikan.Inklusi.M asih.Diabaikan

(November, 2011). Pendidikan inklusi masih belum memadai. Diakses pada tanggal 23 Maret 2012 dari http://www.swarapendidikan.com/headline/pendidikan-inklusi-belummemadai.html 